\title{
Edge Cities in the Era of Megaprojects
}

\section{By: Selima Sultana}

Sultana. S. (2011) "Edge Cities in the Era of Megaprojects" in Stan Brunn (eds.) Engineering Earth: The Impacts of Mega-engineering Projects. PP. 1071-88. NYC: Springer. https://link.springer.com/chapter/10.1007\%2F978-90-481-9920-4_61.

This is a pre-copyedit version of a chapter published in Engineering Earth: The Impacts of Mega-engineering Projects. The final authenticated version is available online at: https://doi.org/10.1007/978-90-481-9920-4 61

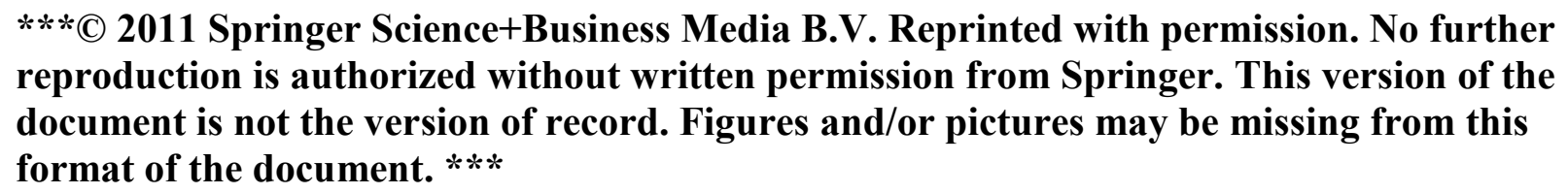
reproduction is authorized without written permission from Springer. This version of the document is not the version of record. Figures and/or pictures may be missing from this format of the document. ***

\begin{abstract}
:
At the beginning of the 20th century almost all of America's office space was clustered in downtowns of cities and towns, but this trend has changed since the freeway construction era after World War II. The freeway era facilitated rapid suburbanization and giant multifunctional concentrations of employment, often with skyscraper buildings located many miles from downtown. Because these appeared to be an entirely new phenomenon, new names were devised to describe them, such as suburban downtowns, technoburbs, or urban villages, but the most well known term was edge city. Edge cities generally imply large scale built landscapes for consumption and the excess investment of capital, iconic architecture and design and distinctive lifestyles. They also display a potential for new freedom from existing ways of building and imagining a city. Ironically, there is confusion in contemporary urban geography because these suburban megaprojects re-create so many of the traditional meanings of a city that they seem to no longer need the city or may even compete with it. Their significance in the contemporary urban system extends far beyond their architectural design and meaning. This chapter seeks to analyze the origin and evolution of edge cities in different local contexts and their associated impacts on the local urban landscapes in terms of physical, economic, and social conditions. It concludes that in the recent decades this type of multifunctional employment concentration is visible in urban peripheries throughout the world with the increasing dominance of new highways and automobiles; however, their future existence is questionable in varying political economies and social cultures.
\end{abstract}

Keywords: Urban Form | African American Family | Office Space | Spatial Mismatch | Corporate Headquarters

Article:

Introduction 
At the start of the 20th century almost all of America's office space was clustered in the downtowns of cities and towns. But during the era of rapid suburbanization and freeway construction after World War II, giant multifunctional concentrations of employment, with skyscraper buildings many miles from downtown, have arisen. While some were noticed as far back as the 1960s (Kersten \& Ross, 1968), it was in the late 1970s and 1980s that they became well known especially as large scale developments. Because they appeared to be an entirely new phenomenon, new names were devised to describe them, such as suburban downtowns (Baerwald 1978; Hartshorn \& Muller, 1986), technoburbs (Fishman 1987), or urban villages (Leinberger, 1988), but the most well known term was edge city (Garreau, 1991).

Edge cities are sites for large scale landscapes for consumption and the excess investment of capital, iconic architecture and design, and distinctive lifestyles. These display a potential for new freedom from existing ways of building and imagining a city (Koolhass, 1995). It is ironic that there is confusion in the contemporary urban geography literature because these suburban megaprojects re-create so many of the traditional meanings of a city that they seem to no longer need the city. They may even compete with it. Urban environments increasingly appear to be so fragmented, disintegrated or fractal that it is difficult to speak about the modern city "which sometimes is ceasing to be modern and [even] to be a city?" (Garcia Canclini, 2001: 3; Koolhass, 1995). Therefore, their existence in the contemporary urban system extends far beyond their architectural design and meaning. The aim of this chapter is to analyze the origin and evolution of edge cities in different local contexts and their associated impacts on the local urban landscapes in terms of physical, economic, and social conditions.

\section{The Origin of Edge Cities in the U.S.}

While it is still common to depict suburbs as mere bedroom communities, it was obvious by the 1960s that they were becoming the center of retail activity in many cities, and it was not long after that other activities followed. From the 1960s to the early 1980s, U.S. businesses kept the demand for new office space at a high level in many cities because of corporate acquisition, mergers, and relocations of corporate headquarters (Feagani \& Parker, 1990). During that period hundreds of major office towers and other corporate buildings were built, amounting to about $36 \%$ of all office space ever built in the U.S. As a result, office building construction became one of the most successful and profitable real estate businesses ever.

The suburban office space development boom occurred largely in the 1980s, in response to the massive traffic jams around old downtown and availability of cheaper lands in suburban locations. In fact, $58 \%$ of the suburban office space that exists today was built during this office building boom, and the overall trend toward suburbanization continued at a rate that job growth in suburban areas outpaced population growth (Lang, 2003). Suburban office space provided something that downtown office buildings were not able to provide: abundant free parking, a perfect destination for car owners. The wave of decentralized office development that followed in suburban locations made these employment concentrations seem like a downtown.

However, not all residential suburban areas evolved into an edge city. To form an edge city a suburban area had to be in close proximity to an older downtown or a matured edge city and have proximity to an educated and skilled labor force, as well as buying power so that firms 
could locate in close proximity to their workers and customers. The success of the edge cities was and is still determined by the types of employment activities and their affect on housing attractiveness in adjacent areas.

\section{What Is an Edge City?}

Garreau suggested five criteria for defining an edge city, which requires at least $464,515 \mathrm{~m}^{2}(5$ million $\left.\mathrm{ft}^{2}\right)$ of leasable office space accompanied by $55,742 \mathrm{~m}^{2}\left(600,000 \mathrm{ft}^{2}\right)$ of leasable retail space; it should have more jobs than bedrooms; was nothing like a city thirty years ago; and the place is known as single end destination (it has it all: entertainment, recreation, shopping etc). These criteria pose a number of difficulties in spatially defining them or studying them systematically. He did not discuss the number of jobs, any requirement for job or building density, or the contiguity of these places. Neither did he discuss how these places fit into census geography or if they were in unincorporated areas. Much of his approach was based on identifying megascale developments at suburban locations, and particularly skyscrapers in suburban Washington, DC.

A large body of literature has developed about how to define and identify these places (e.g., Anderson \& Bogart, 2001; Bogart \& Ferry, 1999; Forstall \& Greene, 1997; Fujii \& Hartshorn, 1995; Giuliano \& Small, 1991; McDonald \& Prather, 1994; Pivo, 1993; Sultana, 2000). Those works typically use the number and density of workers within contiguous census zones such as tracts or smaller units. These approaches look for employment concentrations rather than clusters of tall buildings. In fact most of Garreau's edge cities would not qualify by these definitions. He himself was not consistent in defining some of his own edge cities with his office floor space criteria. For example, none of the edge cities in New Jersey that Garreau mentioned in his book qualify by his definition (Lang, 2003). Some of them are so close to downtown that they are essentially extensions of downtowns, such as Midtown and Buckhead in Atlanta. Also, Garreau believed that most of the edge cities clustered around retail centers, but empirical study does not support this. Rather the closest regional malls were found miles away (Lang, 2003).

In my view edge cities can be defined as multifunctional employment centers that can be proactive economic boosters for the urban cores. Edge cities may have their own government, but would not exist in anything like their present form if not for the suburban expansion of their larger neighbor. These edge cities are activity nodes within a metro area's economic network, not miniature cities themselves.

\section{Building Edge Cities}

While edge cities are dependent on public infrastructure such as highway networks, with few exceptions (such as the I-80/284 center in New Jersey), the majority of edge cities in the U.S. were privately built (Bontje \& Burdack, 2005). Large scale developers usually strategically predict a location for business clusters by taking into consideration the economic activities of firms, the behavior of households, and competition between land prices in downtowns (Henderson \& Mitra, 1996). They also may manipulate the bureaucratic process, particularly the zoning board. Many of the nation's largest edge cities were created by Gerald Hines, the legendary developer of several Galleria Malls in various cities (Lang, 2003). These include 
Gallerias in Dallas and in Uptown and Sugar Land in Houston, Texas, as well other edge cities without a Galleria, such as Westlake Park in Houston and Denver Technology Center in Denver. To prevent downscale retail centers around his developments, Hines influenced the zoning board to have surrounding land zoned for office space, hotels, and multifamily housing, with the goal of promoting the formation of large scale, mixed-use edge cities.

Generally, developers purchase farmland or undeveloped land from large landowners/speculators or from local farmers. For example, the Perimeter Center Area business cluster in Atlanta was a planned development by Michael Gearon. He purchased farmland in 1969 when he had learned about the opening of the I-285 beltway. Gearon studied the pattern of interchanges with major radial arterials in order to determine the best location for his office complex. He chose a site adjacent to the Ashford-Dunwoody Road exit because it represented an ideal location due to the lack development, favorable street network, and desirable green space with the relatively affluent Dunwoody community to the north and east. Gearon realized that new high-rise office space and large-scale shopping mall (Perimeter mall) would add prestige to the area for professional households (Hartshorne \& Muller, 1989).

The scale of these projects can be vast. CityCenter in Las Vegas, at $\$ 8.6$ billion is the most expensive privately funded development in U.S. history. It will contain three hotel/condominium skyscrapers, two additional condominium towers, and a casino and shopping center (Freiss, 2009). However, this is just one of a large collection of multibillion dollar resort hotels along the Las Vegas Strip. Garreau listed the Strip as an edge city, though there is essentially no office employment, but it is outside the city limits of Las Vegas and was mostly empty land 30 years ago (documented by Venturi, Brown, \& Izenour, 1972).

On the other hand, some edge cities are really an outgrowth of community effort. A committee of government, university, and business leaders founded the Research Triangle Park in Durham, North Carolina in January 1959 as a model for research, innovation, and economic development. By establishing a place where educators, researchers, and businesses come together as collaborative partners, the founders of the Park hoped to change the economic composition of the region and state, thereby increasing the opportunities for the citizens of North Carolina. John Caldwell, the Chancellor of North Carolina State University, led the project. The office space has increased from only $18,581 \mathrm{~m}^{2}\left(200,000 \mathrm{ft}^{2}\right)$ in 1960 to more than 2.09 million $\mathrm{m}^{2}(22.5$ million $\mathrm{ft}^{2}$ ) in 2007. In another example, government activity forms the nucleus of several edge cities in Virginia at Quantico (FBI and Marine Corps), Crystal City (Pentagon) and Langley (CIA headquarters). Tampa's Westshore also serves McDill Air Force Base and Clear Lake is located next to the NASA Manned Spaceflight Center near Houston.

The financing of megaprojects can be a complex process. Several powerful groups are involved: developers, financial institutions (domestic and foreign), private investors, top corporate executives, national chain stores, and smaller business tenants, and all must interact with various government officials (Feagani \& Parker, 1990). However, developers are the shapers of these processes as they secure the construction and long-term financing, bringing banks and other financial institutions into the project. Hence since the late 1970s a new trend can be seen in the close organizational ties between lending organizations and developers. For example, Prudential and New York's Guardian Life Insurance Company have been joint-venture partners in major 
New York office projects. Typically, the developers have leverage on prominent bankers for buying and developing property with other people's cash. In this case private developers may retain majority ownership for decades, and their initial plans will contractually or institutionally define city development for decades.

Developments can also involve public and private participation, with various arrangements involving the financing and provision of public infrastructure and services. Sometimes the developer is even a government entity that buys up, develops, and sells off space for profit. Regardless, there is effectively one large agent in each of these scenarios who develops these agglomerations on a massive scale (Henderson \& Mitra, 1996). In today's global market, money can also come from foreign sources such as from Europe, the Middle East, and Japan. For example, in Sunbelt cities one-fifth or more office construction money often comes from foreign sources such as Nippon Life Insurance and Kumagi Gumi of Japan (Feagani \& Parker, 1990). Table 1 shows some of the megadevelopers by region in the U.S.

Table 1. Selected megadevelopers by region in US

\begin{tabular}{|ll|}
\hline South & CBL and Associates, Based in Chattanooga \\
& Turnberry and Associates, Florida \\
& Premier Properties, Indianapolis, Virginia Beach \\
& MG Herring, Dallas \\
\hline Northeast & Kraft Group, Boston Area \\
& Simon Properties, KenAM, Meadowlands \\
& Donald Trump, NY and NJ \\
& Sturbridge Associates, Maryland \\
\hline West & Centra, Nevada \\
& Marcerich, Phoenix \\
& Las Vegas/Beverly Hills \\
& Steve Wynn, Las Vegas \\
& Harsch Investment Properties, Oakland \\
\hline Midwest & Donald Trump, Chicago Tower \\
& Gershman, Brown and Associates, Indianapolis \\
\hline
\end{tabular}

\section{Characteristics of Edge Cities}

Edge cities often emerge along suburban freeways or near airports, and generally in the wealthier parts of metropolitan areas (Lang, 2003) (Fig. 1). The most famous two edge cities in Atlanta, Cumberland-Galleria and the Perimeter area, are located along the I-285 beltway and have high median housing values ( $\$ 300,000$ or more). Instead of a traditional street grid common in downtowns and older neighborhoods, their street networks are characteristic of postwar suburban construction, and are typically based on a hierarchical system of winding parkways that feed into arterial roads or freeway ramps. They often have a considerable mileage of private roads serving individual properties. 


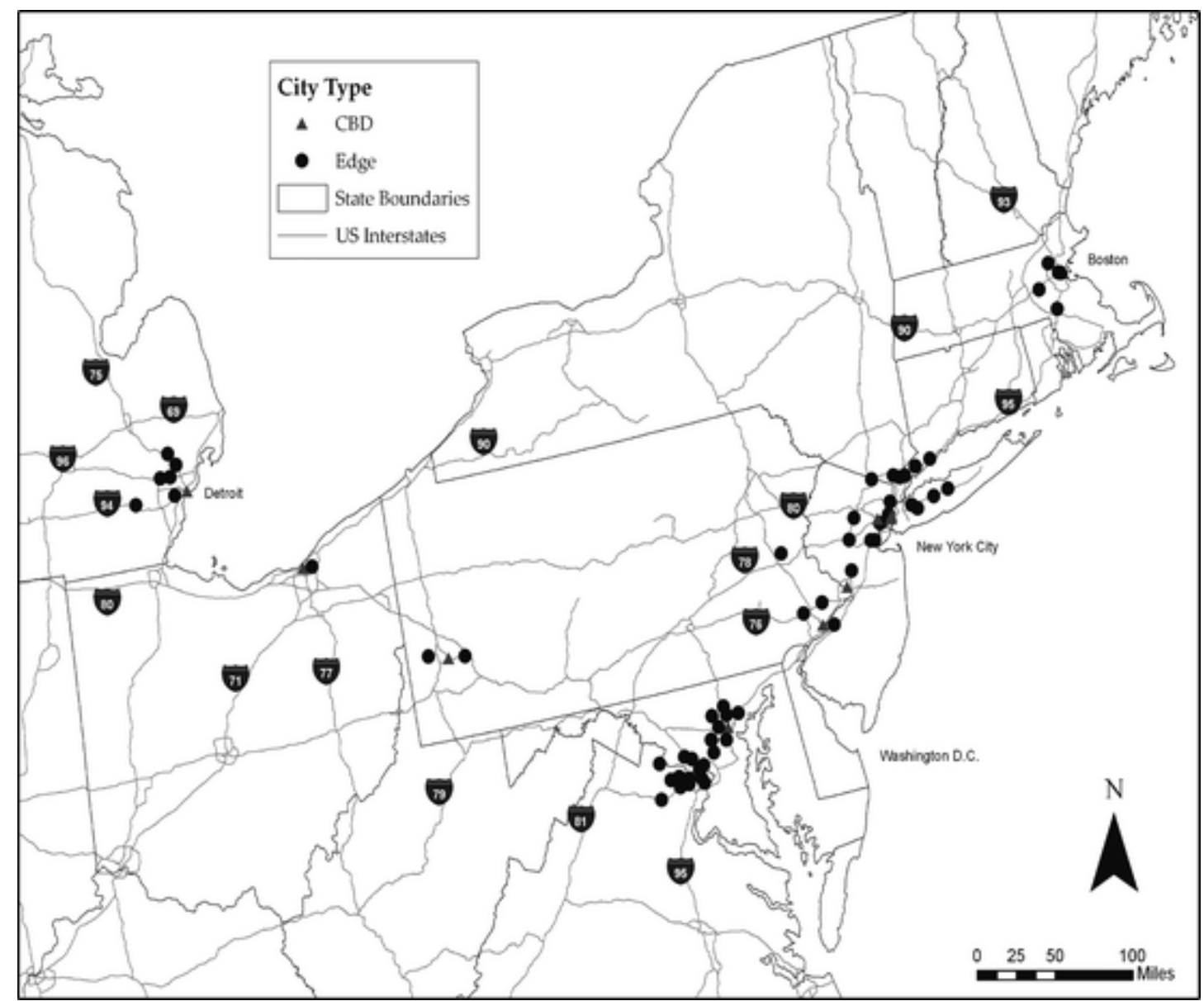

Fig. 1. Location of selected edge cities in North East US. (Cartography by Mathew Catanzarite)

In general, these are areas of lower building densities than downtowns, with large buildings widely separated from others by grass and parking lots with an excessive use of land area. For example, in regards to the Cumberland-Galleria and Perimeter areas in Atlanta, each has have a larger land area than downtown, but they also have a lesser density and fewer workers. Cumberland-Galleria includes 7,205 ha (17,805 acres) with more than four workers per .405 ha (per acre), compared to 3,493 ha (8,631 acres) for Perimeter, and 3,387 ha (8,370 acres) in downtown Atlanta (CTPP, 2000). However, the total number of workers in downtown Atlanta is double that of Cumberland-Galleria and almost three times more than the Perimeter area. Roadways in these areas often lack sidewalks, and combined with the low densities often make it obligatory for workers to drive between adjacent buildings (Downs, 1992). These areas typically have limited public transportation service (if any), with workers entirely dependent on driving their own cars. As a result, a sense of place or community seems to be lacking in many edge cities.

The economic activity within edge cities shows some variation, as some are based on back office activities such as high-tech, financial and producer services. Others may be manufacturing production, and still others are mixed with corporate headquarters (such as Tyson corner, Virginia; Cumberland-Galleria and Perimeter area in Atlanta) (Bingham et al., 1997; 
Lang, 2003). Unlike downtown, museums, historical sites, landmarks, and prominent civic structures are lacking in most edge cities.

\section{Metropolitan Impacts of Edge Cities}

As far back as the 1960s Webber (1963) and Vance (1964) explored the idea of separate urban realms, based on their experience with the San Francisco-Oakland metropolitan area. They suggested that people living in one realm may live, work, shop, and recreate entirely within one realm and seldom stray into another. The visibility of edge cities led to the polycentric model of urban structure, with the traditional downtown now just one of many employment centers, though with land uses still depending on distance from these centers. These centers were assumed to be the focus of commuting trips, leading to the expectation that polycentric cities would shorten the journey to work because more workers would be able to locate closer to their workplace in a city with multiple centers.

However, the evidence for this explosion is mixed. Despite the mass relocation of jobs to the suburbs from 1977 to 1988, the mean journey to work for suburban Americans only increased from 17.06-17.86 km (10.6-11.1 mi) during this period (Klinger \& Kusmyak, 1989). Since then commuting times have increased slightly, though with a slight decrease since 2000 (Crane \& Chatman, 2004; CNN, 2006). The fact that there has been only a modest increase has been used as evidence that households are relocating to maintain desirable commuting times despite increases in traffic congestion (Levinson, 1998).

Though some employees live nearby and have shorter commute times (Cervero \& Wu, 1997; Sultana, 2000, 2002), overall commuting patterns at edge cities are more complicated than for traditional downtowns. Commuting patterns are no longer in one direction (suburb to downtown), as crisscrossing suburban-to-suburban commuting has become so prevalent that most employees experience a longer commute than the polycentric model would predict.

The evidence for non-overlapping shopping realms was found lacking for Atlanta (Fujii \& Hartshorn, 1995), and attempts by the city of Phoenix to designate neighborhood centers for shopping or recreation, with the expectation that these would become a part of resident's behavior, were also unsuccessful (Pickus \& Gober, 1988). However, Portland, Oregon, has put this idea into the future land use and transportation plan, with the goal of creating higher density regional employment and residential centers connected by transit (Metro, 1997).

Edge cities provide a specialized labor market with a fairly specialized range of employment. The growth of edge cities, therefore, can exacerbate a region's job-housing imbalance by providing a great concentration of employment with the potential for little housing nearby. They can also increase the potential for spatial mismatch by widening the distance between economic opportunities and concentrations of low income and African American families. As noted earlier, most of edge cities are located in the wealthy and largely white residential areas of metropolitan areas. All the edge cities in Atlanta (except for Hartsfield airport), are located in the northern part of the city, which is the wealthiest part of the metro area, whereas less wealthy African American families are concentrated in the central city and middle income African Americans in southern suburban areas (Sultana, 2005). The Cumberland-Galleria and Perimeter edge cities are the 
wealthiest areas in Atlanta with extremely median housing values $(\$ 300,000$ or more) in surrounding neighborhoods, which force away moderate and low-income families (Sultana, 2002).

Likewise, while edge cities may have helped reduce the gendered division of space within cities (England, 1991), they have not been accompanied by a change in the gender division of labor, and the relative isolation within which workers work within buildings does little to overcome the social isolation that hinders mobility (England, 1993; Hanson \& Pratt, 1988). Edge cities do not just reflect urban disparities; they can perpetuate or increase them. A study in Cleveland, Ohio, found that employment growth in edge cities may have profound impact on the regional housing development and population growth further outward (Ding \& Bingham, 2000), creating their own suburban bedroom community at the expense of more complicated urban geographies over a larger spatial scale.

\section{Edge Cities in Charlotte, North Carolina}

Charlotte, North Carolina is the nation's fifth largest urban region and is a rapidly growing metropolitan area with 1.7 million people in 2009. Downtown Charlotte (known as Uptown) is an impressive collection of high-rise office buildings, including the $265 \mathrm{~m}(871 \mathrm{ft})$ tall Bank of America headquarters, symbolizing the city's role as the second largest banking center in the U.S. Uptown is a classic example of an older downtown, characterized by small building lots on a dense grid dating back to 1770 . It has seen considerable growth in employment, retail, and residential population in recent decades. However, the city also provides excellent examples of the growth of edge cities, though not all meet Garreau's criteria.

Currently, Charlotte (Fig. 2) has one edge city, Southpark, and two emerging edge cities: College Place and Ballantyne Village. Southpark has been absorbed by Charlotte through 40 years of annexation and is currently the second largest business district in the state with $392,980 \mathrm{~m}^{2}(4.23$ million $\mathrm{ft}^{2}$ ) of office and retail space (Fig. 3). It was created by the son-in-law of Governor Cameron Morrison on the family farm. James Harris and several of his friends (who were part of the Belks Department Store and Ivey Department Store dynasties) constructed South Park Mall in 1970 on 38.6 ha (95.5 acres) of land, home to some of the country's finest retailers, including Neiman Marcus. Charlotte's "old money" migrated toward Southpark as the growth of the city outstripped the available high-end residential property near downtown. Today the Southpark area boasts a median household income nearing $\$ 200,000$ with only a few census blocks below $\$ 75,000$. The vast majority of employment is in medical arts and other financial and professional sectors. The area contains seven of the highest median family income census blocks in Mecklenburg County. In these blocks the white only population ranges from 95 to $100 \%$. The average ages of homes ranges from 1958 to 1988 (measured by 2000 Census data) indicating an older but economically viable residential base. As can be seen, Southpark has a collection of large buildings, but at much lower densities than uptown. The tallest buildings have only 14 floors. There is no street grid and buildings occupy only a small portion of their lots. Private access roads provide automobile access to most buildings. 


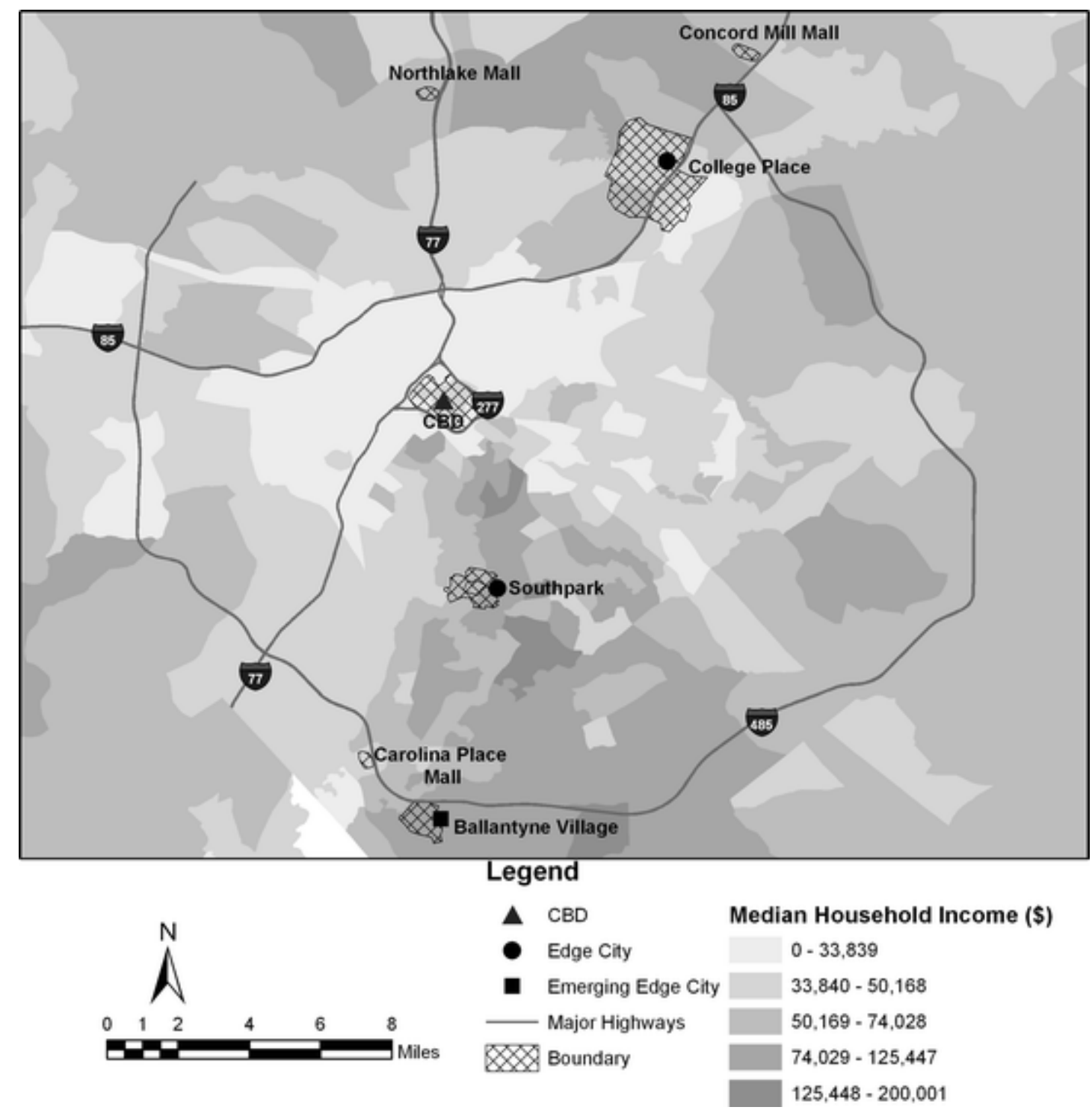

Fig. 2. Edge cities with median household income in Charlotte MSA, North Carolina

Today the northern tip of the Southpark area is generally considered to be bounded on the north by a hospital and medical district that contain two level-one trauma hospitals and the corporate headquarters of Carolinas Medical and Presbyterian Hospitals. Together these entities employ nearly 40,000 workers. The core of Southpark is Southpark Mall and the southern boundary is the Quail Hollow and Carmel County Clubs, both private golf clubs that host a number of PGA and LPGA events per year. Most of Charlotte's medical community and a great deal of its financial community live in Southpark.

College Place is located $12.8 \mathrm{~km}(8 \mathrm{mi})$ north of Uptown (see Fig. 2). It is greatly influenced by the city of Concord and the population of Cabarrus County, although planners saw College Place as a way to relieve the development pressure on south Charlotte. Hugh McColl, the banking giant who made Charlotte the second largest banking center in the U.S., was important in its development, though he preferred to keep banks and skyscrapers in Uptown. The area did not really begin to take off until traffic problems in south Charlotte became acute in the early 1980s 
and when IBM located in College Place. Charlotte's University Research Park is the private/corporate center of this edge city and was begun by city leaders and Duke Power in the early 1960s as a location for the University of North Carolina at Charlotte and other tenants including Duke Power, IBM, Southern Bell, AT\&T, American Express, and Dow Jones. A number of 12 floor office buildings exist in this area totaling $343,741 \mathrm{~m}^{2}\left(3.7\right.$ million $\left.\mathrm{ft}^{2}\right)$ of office and retail space, but the closest regional mall, Concord Mills, is located several miles away.

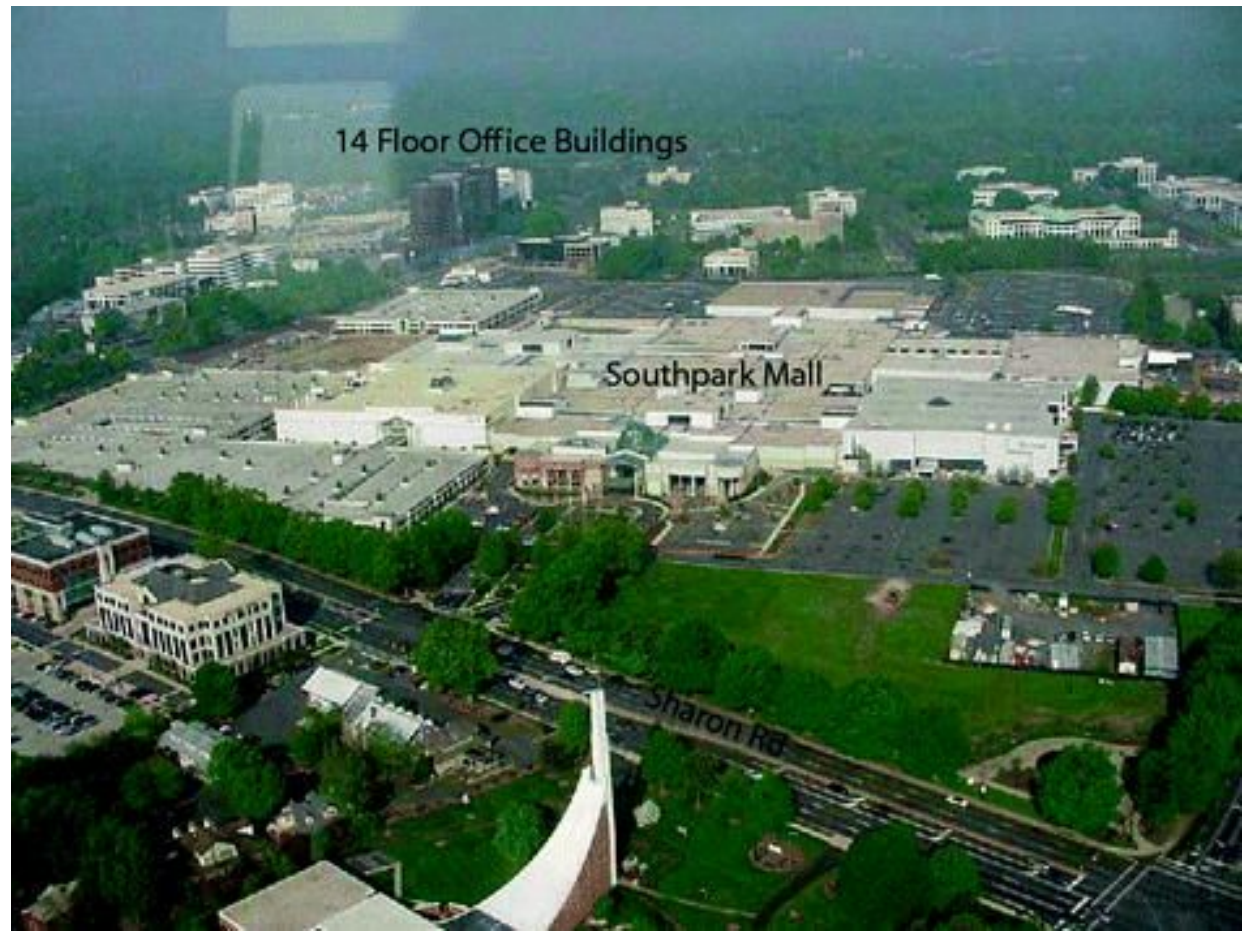

Fig. 3. Southpark, Charlotte, North Carolina area looking to west

College Park boasts a very high Asian population and is perhaps the most ethnically diverse of the three edge cities in Charlotte. The area is also most diverse in employment with medical arts, education, and professional services having nearly equal shares of the employment mix. Only two of Mecklenburg's top median family income census blocks are located in this area, with an average housing age of 15 years in 2000 . These census blocks are also only $90 \%$ and $87 \%$ white, indicating a slightly greater degree of ethnic distribution of wealth.

This area is the most spread out in spatial terms with multiple cores and very low densities (Fig. 4). A branch of Carolina's Medical Center forms the northwest edge while the Charlotte Motor Speedway and an accompanying mall are to the northeast. Both of these have an important economic connection, as the northwest edge is connected to Duke Power's Maguire Nuclear Station and the northeast being the connection to Phillip Morris. The University of North Carolina at Charlotte forms the southeast corner while the southwest corner is a collection of office parks developed over the last 20 years. 


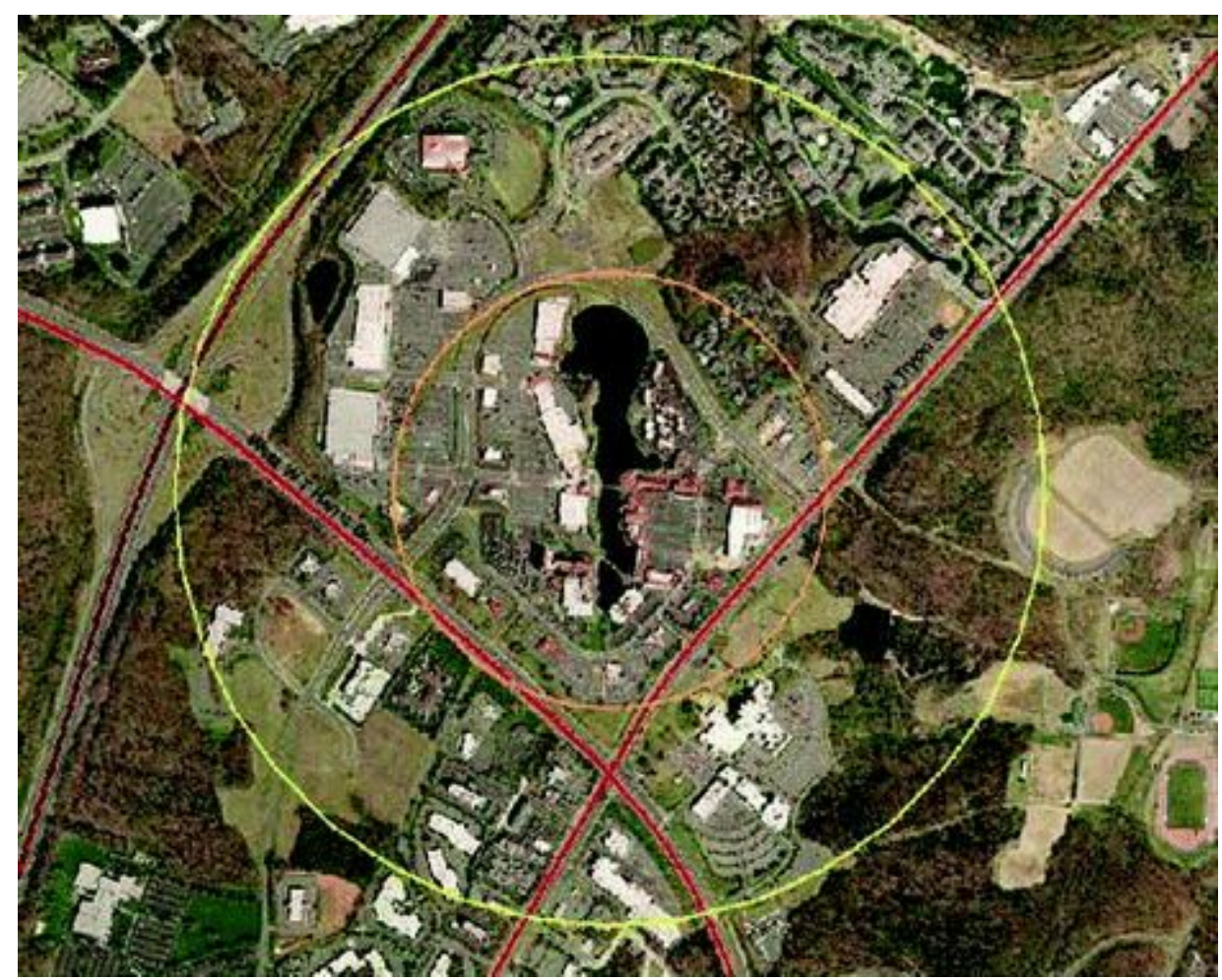

Fig. 4. Eastern section of college place, Charlotte, North Carolina

College Place has not yet developed a fully independent identity as jobs outstrip residences, and many residents are transient as they are among the 30,000 students associated with UNCCharlotte. A distinct identity is further complicated by the fact that College Place crosses into Cabarrus County, touches the city of Concord to the northeast, and nears the three rapidly growing communities of Davidson, Cornelius, and Huntersville near the Iredell County line to the northwest.

A newer emerging edge city is called Ballantyne Village (see Fig. 2), located on Governor Morrison's old hunting preserve about $8 \mathrm{mi}(12.8 \mathrm{~km})$ south of Uptown. Ballantyne Village's core is a 378 ha (535 acres) corporate park and 809 ha (2,000 acres) resort, residential development and golf course totaling $268,490 \mathrm{~m}^{2}\left(2.89\right.$ million $\left.\mathrm{ft}^{2}\right)$ of office and retail space (Fig. 5). Immediately adjacent to this is the Carolina Place Mall and a number of other retail developments. The residents in the Ballantyne area are significantly more diverse than in the Southpark area, though occupations in this area are nearly the same as in Southpark. Much of Ballantyne is so new that the 2000 Census captures less than $40 \%$ of the population currently living there. It has one of Mecklenburg County's wealthiest neighborhoods, with a median family income of $\$ 147,000$ and an average home age of less than 5 years in 2000.

There is no reason to assume there will not be additional employment clusters in Charlotte. It is possible the next one will be the UNC-Charlotte Research Park in Kannapolis. This is about $7 \mathrm{mi}$ $(11.2 \mathrm{~km})$ north of College Place and outside the Charlotte/Mecklenburg County jurisdiction.

Given that these edge cities are located in predominantly wealthy white areas it should be no surprise that the accessibility to jobs of African American workers is half that of white workers 
in Charlotte (Sultana, 2008). Hispanic workers have the lowest level of accessibility to work: almost ten times less than African American workers and 20 times less than white workers. This observation provides another example of how the rise of edge cities can exacerbate a region's job-housing imbalance and spatial mismatch by widening the distance between economic opportunities and the concentration of low income and African American families.

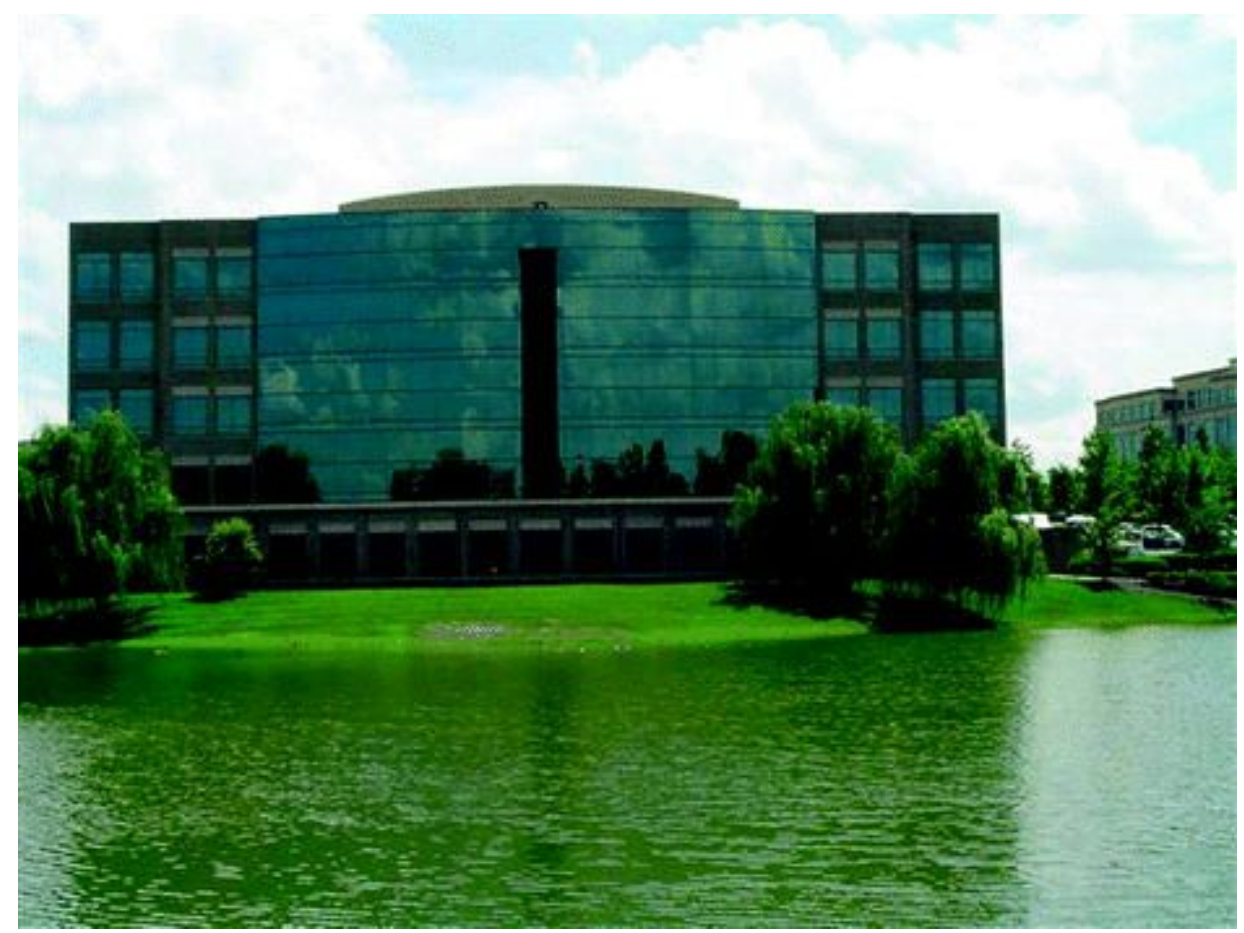

Fig. 5. Typical building in Ballantyne village office park in Charlotte, North Carolina

\section{Cross Cultural Perspectives on Edge Cities}

Western Europe has also experienced new suburban economic poles, though these differ from the American experience (Bontje \& Burdack, 2005). Many of these developments result from a public-private partnership, they have far longer and richer histories of urban growth compared to the U.S. European edge cities also try to meet high sustainability standards (Bontje, 2004; Phelps, Nick, Dimitris, Andrew, 2006). As a result European edge cities are not a direct copy of American models.

While the transition to a market economy created a newly emerging wealthy class in Russia, foreign developers are building speculative suburban communities with western style apartment complexes and even gated communities (Brunn, Hays-Mitchell, \& Zeigler, 2008). Though Moscow has quickly developed financial and business centers to attract foreign investment, but they are still centrally located such as Moscow City in Moscow (Bontje \& Burdack, 2005). There are number of small satellite cities in the periphery, however. Given the pace of increasing commercial and private vehicle use in Moscow, congestion in the central business areas is no longer just the phenomenon of morning or afternoon rush hours, and more accessible peripheral locations appear increasingly desirable. 
The North American edge city was fundamentally impossible without the automobile, and the lack of an automobile-oriented transport system has worked against the development of such edge cities in the developing world. However, many satellite towns or satellite cities have appeared at the fringe of large Asian cities such as Mumbai, Delhi, Kolkata, Dhaka, and Beijing. Conceptually, satellite cities could be (and once were) self-sufficient communities outside of their larger metropolitan areas, but they have become interconnected due to the suburban expansion of the larger metropolis.

Recently, India welcomed its first edge city megaproject, Odyssey Science City in Anantapur; it is one of the poorest and most undeveloped parts of Andhra Pradesh (SkycraperPage Forum, 2009). This project is funded by foreign investors from Australia and Singapore. This Odyssey Science City will be built on 26,305 ha (65,000 acres) of land with an investment of $\$ 25$ billion, and will employ over two million people. The city will be serve as a national center for technology and innovations and will host 500 companies in every field of manufacturing, financial services, retailing and transportation. It is no doubt that with the global shift of industrial capital from developed countries to India, the country will continue to foster new urban places with modern style high-rise office space and retail clusters in rural areas, but at the same time displaceing poor local residents.

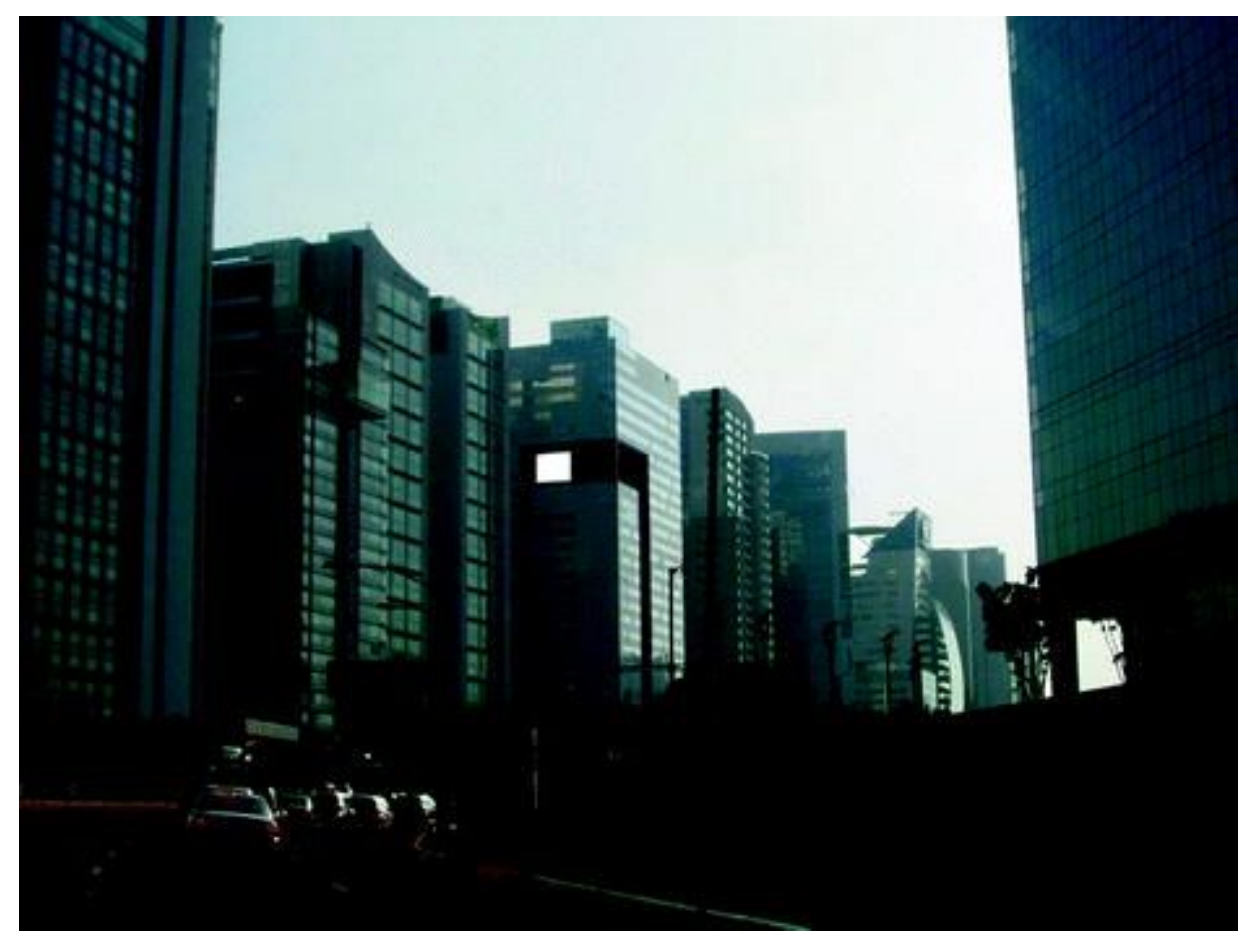

Fig. 6. Street view of Santa Fe, Mexico

With the same philosophy of attracting foreign investment, megaproject edge cities have been present in Mexico's landscape since the late 1980s. The Santa Fe urban megaproject (Fig. 6) was developed with an area of 946 ha (2338 acres) on the western fringe of Mexico City. To justify this city, the land was taken from the original users after local politicians presented an image of this area as underutilized. Santa Fe is now a major business district consisting of many high-rise buildings surrounding a large shopping mall, which is currently the largest mall in Mexico 
(Centro Commercial Santa Fe). There are three college campuses and the area has more jobs $(70,000)$ than residents (about 5,000). Since Santa Fe was developed in the 1980s, it also has many problematic characteristics shared by American edge cities, such as being a car centered development with few roads connecting to central Mexico City, public transportation is almost nonexistent, and public space for pedestrians is very limited.

Similarly, with the booming market economy in China there are edge city developments created to open new spaces for economic growth, and which cannot be explained by urban expansion and suburbanization (Wu \& Lu, 2008). Unlike many American edge cities that are generally clustered around office and retail space, China's edge cities are related to manufacturing development, especially for export oriented production. They are well connected with other cities by rail, and form part of a polycentric megaurban structure in areas such as such as Yizhuang of Beijing and Kunshan adjacent to Shanghai (Yi, Li, \& Phelps, 2008). However, social space in these mega-urban places is changing quickly. Before the market economy, urban social space was more homogeneous and based on occupation category. For example, professors lived near universities, while manufacturing workers lived close by factories. Today it is more heterogeneous and increasingly based on factors such as affordability and individuals identity (such as migrants vs. local residents, ethnicity, etc.) (Wu \& Lu, 2008).

While edge cities can be found in many countries, they represent very different things in different parts of the world. Perhaps a more appropriate term for these would be "peripheral business cluster," as they all share similarities to the function of North American edge cities and require massive amounts of land and capital investment. These places share important similarities as they are distinctly new and economically vibrant symbols of modernity and urban growth. They all developed during the time when the car culture became dominant in each particular country. However, there are other characteristics they do not share, such as their political economy and social culture, and they have varying spatial conditions that produce distinct urban forms.

\section{The Future of Edge Cities}

All cities face challenges in the 21 st century, including changing family structure, the impacts of information and communication technology, the possibility of disruptions to the supply of fossil fuels that run automobile oriented cities, and the specter of global climate change (Newman, Beatley, \& Boyer, 2009). Traditionally, suburban areas surrounding edge cities were popular for two-parent households. If there is nothing in America's history to suggest that Americans will dispense with their love affair with a yard when they are in their child rearing years, the edge cities are likewise not that attractive for them because of congestion. These types of family are more likely to move out to more peripheral or exurban locations. Married couple families with children are becoming less and less common, but edge cities are also less likely to have downtown assets that will attract childless residents.

Edge cities are especially vulnerable to fossil fuel disruptions as they have a high dependence on automobiles. Because most are built at automobile scales, mass transit frequently cannot serve them well. Pedestrian circulation within an edge city is impractical even if residences are nearby. Increasing the density of these places will be difficult because of resistance from nearby 
residents. Rather than a new era in urban form, edge cities may turn out to have been a brief 20th-century phenomenon (Lang, 2003). Revitalization of edge cities may in fact be the major urban renewal project of the 21 st century.

The importance of edge cities can also be questioned by comparing the polycentric model with both the older monocentric model as well as a non-centered or edgeless urban form (Cervero, 1993; Fujii \& Hartshorn, 1995; Lang, 2003). "Edgeless" refers to the wide dispersion of functions and activities, such that retail and wholesale functions are widely distributed over many locations but do not constitute specialized commercial nodes, which often appear in the early stages of suburban office development (Fujii \& Hartshorn, 1995). With the impact of information technology, workers and firms have now more flexibility in their location choices. In fact, more office space was added after 1990 in sprawl locations than in edge cities (Lang, 2003). America's many inner suburbs declined while outer suburbs or center city gained population after 2000 (Lucy \& Phillips, 2006). With large amounts of population having moved to the outer suburbs and away from edge cities, the idea of establishing an employment center closer to the labor force makes sense. As a result, today's norm for growth of metropolitan areas in U.S. is more of a hybrid model (polycentric and dispersed coexisting) than Garreau's claim of edge cities as the norm for the growth of America's future metropolises.

However, it can be expected that edge cities will continue to develop across the globe during the next half century. Edge cities may be most likely in developing countries increasingly involved in the global economy, such as China, Malaysia, Indonesia, India, Philippines, Argentina, Brazil, as well as Moscow, Russia. In the U.S., new edge cities will likely be found in the Sunbelt area, particularly in mid-sized and fast growing metropolitan areas such as Atlanta, Charlotte, Raleigh, Las Vegas, and South Texas along the U.S.-Mexico border (especially McAllen). Edge cities are clearly common in cities well placed within the urban hierarchy, though it may be that these developments are working their way down to less important places, especially those that are susceptible to real estate booms associated with new industries or economic activities located away from traditional economic cores.

\section{Conclusion}

It is noteworthy that edge cities seem to be a preoccupation of the postwar Baby Boomer generation (of which Garreau, born in 1948, is a member). These developments appeared at a time when Baby Boomers were entering professional life and provided a clear break from the urban patterns of their youth. It is hard not to notice that those developments that are changing middle or upper class white suburban areas have received tremendous attention. While public housing projects, downtown convention centers or festival marketplaces, or even satellite industrial districts are also large scale developments that may involve substantial private investment and master planning, they do not receive the same attention.

The substantial literature on edge cities avoids dealing with the many substantial problems cities face (such as worsening school and residential segregation, poverty, deindustrialization, or the environmental legacy of industrialization). Yet the growth of edge cities cannot be separated from issues of white flight and spatial mismatch. While edge cities may represent a new urban form, they clearly do not represent a new socioeconomic order for workers employed in these 
areas (and those excluded from employment by distance and lack affordable housing). There are serious threats to their future, and even the possibility that they will require a need for massive public subsidies or renewal funds. The benefits of these megastructures, as well as their current and potential future costs, need to be assessed carefully.

The creation of most edge cities includes the historical fact that all edge cities were once low density suburban communities with a low density of economic activities (Lang, 2003). The high density Sandy Spring and Roswell areas of Atlanta are examples with a low density of employment as recently as 1990. These are not static features of the urban landscape, and their future remains wide open. It would clearly be naïve to assume that all edge cities have (or will) follow the same conceptual philosophy and have the same appearance. Edge cities have not proven as easy to identify and study as Garreau's book suggested, and the variety of such places will surely increase in the future. As with other urban and economic megastructures, their final impacts on cities will be debatable for some time to come.

\section{References}

Anderson, N. B., \& Bogart, W. T. (2001). The structure of sprawl: Identifying and characterizing employment centers in polycentric metropolitan areas. American Journal of Economics and Sociology, 60, 147-169. CrossRef Google Scholar

Baerwald, T. J. (1978). The emergence of a new "downtown." Geographical Review, 68, 308318. CrossRef Google Scholar

Bingham, R. D., Bowen, W. M., Amara, Y. A., Bachelor, L. W., Dockery, J. et al. (1997). Beyond edge cities. New York: Garland. Google Scholar

Bogart, W. T., \& Ferry, W. C. (1999). Employment centers in greater Cleveland: Evidence of evolution in a formerly monocentric city. Urban Studies, 36, 2099-2110. CrossRef Google $\underline{\text { Scholar }}$

Bontje, M. (2004). Sustainable new economic centers in European metropolitan regions: A stakeholders' perspectives. European Planning Studies, 12(5), 703-722. CrossRef Google $\underline{\text { Scholar }}$

Bontje, M., \& Burdack, J. (2005). Edge cities, European style: Examples from Paris and the Randstad. Cities, 22(4), 317-330. CrossRef Google Scholar

Brunn, S. D., Hays-Mitchell, M., \& Zeigler, D. J. (Eds.). (2008). Cities of the world: World regional urban development. New York: Rowan and Littlefield. Google Scholar

Cervero, R. (1993). Changing live-work spatial relationships: Implications for metropolitan structure and mobility. Paper Prepared for the 4th international workshop on Technological Change and Urban Forms: Productive Sustainable Cities, Berkeley, CA. Google Scholar 
Cervero, R., \& Wu, K. (1997). Polycentricism, commuting, and residential location in the San Francisco Bay area. Environment and Planning A, 29, 865-886. CrossRef Google Scholar

CNN. (2006). Study: Average commute shorter, albeit by 24 seconds. Retrieved September 12, 2006, from http://www.cnn.com

Crane, R., \& Chatman, D. G. (2004). Traffic and sprawl: Evidence from U.S. commuting 19851987. In H. W. Richardson \& C. C. Bae (Eds.), Urban sprawl in Western Europe and the United States (pp. 311-325). Aldershot: Ashgate. Google Scholar

CTPP. (2000). Census Transportation Planning Package data. Washington, DC: U.S. Census Bureau. Google Scholar

Ding, C., \& Bingham, R. D. (2000). Beyond edge cities: Job decentralization and urban sprawl. Urban Affairs Review, 35(6), 837-855. CrossRef Google Scholar

Downs, A. (1992). Stuck in traffic: Coping with peak hour traffic congestion. Washington, DC: The Brookings Institution. Google Scholar

England, K. V. L. (1991). Gender relations and the spatial structure of the city. Geoforum, 22, 135-147. CrossRef Google Scholar

England, K. V. L. (1993). Suburban pink collar ghettos: The spatial entrapment of women? Annals of the Association of American Geographers, 83, 225-242. CrossRef Google $\underline{\text { Scholar }}$

Feagani, J. R., \& Parker, R. (1990). Building American cities: The urban real estate game. Englewood, NJ: Prentice Hall. Google Scholar

Fishman, R. (1987). Bourgeois utopias: The rise and fall of suburbia. New York: Basic Books. Google Scholar

Forstall, R. L., \& Greene, R. P. (1997). Defining job concentrations: The Los Angeles case. Urban Geography, 18, 705-739. CrossRef Google Scholar

Freiss, S. (2009). Tower rising in Las Vegas but now, not so high. New York Times February 11, 2009. Retrieved from http://www.nytimes.com. 13 February 2009.

Fujii, T. \& Hartshorn, T. A. (1995). The changing metropolitan structure of Atlanta, Georgia: Location of functions and regional structure in multinucleated urban area. Urban Geography, 16, 680-707. CrossRef Google Scholar

Garcia Canclini, G. (2001). Consumers and citizens: Globalization and multicultural conflicts. Minneapolis, MN: University of Minnesota Press. Google Scholar

Garreau, J. (1991). Edge city: Life on the new frontier. New York: Doubleday. Google Scholar 
Giuliano, G., \& Small, K. A. (1991). Subcenters in the Los Angeles region. Regional Science and Urban Economic, 21, 163-182. CrossRef Google Scholar

Hanson, S., \& Pratt, G. (1988). Reconceptualizing the links between home and work in urban geography. Economic Geography, 64, 299-311. CrossRef Google Scholar

Hartshorn, T. A., \& Muller, P. O. (1986). Suburban business centers: Employment implications. Washington, DC: U.S. Department of Commerce, Project No. RED-808-G-84-5. Google Scholar

Hartshorne, T. A. \& Muller, P. O. (1989). Suburban downtowns and the transformation of metropolitan Atlanta's business landscape. Urban Geography, 10, 375-395. CrossRef Google $\underline{\text { Scholar }}$

Henderson, V., \& Mitra, A. (1996). The new urban landscape: Developers and edge cities. Regional Science \& Urban Economics, 26, 613-643. CrossRef Google Scholar

Jones, G. A. \& Moreno-Carranco, M. (2009). Megaprojects: Beneath the pavement, excess. Retrieved February 23, 2009, from http://eprints.lse.ac.uk/15127

Kersten, E. W., Jr. \& Ross, D. R. (1968). Clayton: A new metropolitan focus in the St. Louis area. Annals of the Association of American Geographers, 58, 637-649. CrossRef Google $\underline{\text { Scholar }}$

Klinger, D. and Kusmyak, J. R. (1989). 1983-1984 National Personal Transportation Study. Washington, DC: Federal Highway Administration, U. S. Department of Transportation. Google $\underline{\text { Scholar }}$

Koolhass, R. (1995). Bigness in office for metropolitan architecture. New York: Monacelli Books. Google Scholar

Lang, R. E. (2003). Edgeless cities: Exploring the elusive metropolis. Washington, DC: Brookings Institution Press. Google Scholar

Leinberger, C. B. (1988). The six types of urban village cores. Urban Land, 47, 24-27. Google $\underline{\text { Scholar }}$

Levinson, D. (1998). Accessibility and the journey to work. Journal of Transport Geography, 6, 11-21. CrossRef Google Scholar

Lucy, W. H., \& Phillips, D. L. (2006). Tomorrow's cities, tomorrow's suburbs. Chicago: American Planning Association. Google Scholar

McDonald, J. F., \& Prather, P. J. (1994). Suburban employment centers: The case of Chicago. Urban Studies, 31, 201-218. CrossRef Google Scholar 
Metro (Metropolitan Service District). (1997). Regional framework plan. Portland: Metropolitan Service District. Google Scholar

Newman, P., Beatley, T., \& Boyer, H. (2009). Resilient cities: Responding to peak oil and climate change. Washington, DC: Island Press. Google Scholar

Phelps, N. A., Nick, P., Dimitris, B., Andrew, D. (2006). Post-suburban Europe: Planning and politics at the margins of Europe's capital cities. New York: Palgrave. Google Scholar

Pickus, J., \& Gober, P. (1988). Urban villages and activity patterns in Phoenix. Urban Geography, 9, 85-97. CrossRef Google Scholar

Pivo, G. (1993). A taxonomy of suburban office clusters: the case of Toronto. Urban Studies, 30, 31-49. CrossRef Google Scholar

SkycraperPage Forum. (2009). High-tech science city to come up in Andhra. Retrieved February 27, 2009, from http://forum.skycraperpage,cin/sgiwtgread.php

Sultana, S. (2000). Some effects of employment centers on commuting times in the Atlanta metropolitan area, 1990. Southeastern Geographer, 41(2), 225-233. Google Scholar

Sultana, S. (2002). Jobs-housing imbalance and commuting in the Atlanta Metropolitan Area: Exploration of causes of longer commuting. Urban Geography, 23(8), 728-749. CrossRef Google Scholar

Sultana, S. (2005). Racial variations in males' commuting times in Atlanta: What does the evidence suggest? The Professional Geographer, 57, 66-82. Google Scholar

Sultana, S. (2008). Race and accessibility to work in Charlotte MSA, NC. Paper presented at the Race, Ethnicity, and Place Conference IV, Miami, FL, 6-8 November. Google Scholar

Vance, J. E., Jr. (1964). Geography and urban evolution in the San Francisco bay area. San Francisco: Institute of Governmental Studies. Google Scholar

Venturi, R., Brown, D. S., \& Izenour, S. (1972). Learing from Las Vegas. Cambridge: MIT Press. Google Scholar

Webber, M. (1963). Order in diversity: Community without propinquity. In L. Wingo (Ed.), Cities and space (pp. 23-54). Baltimore: Johns Hopkins University. Google Scholar

Wu, F., \& Lu, D. (2008). The transition of Chinese cities. Built Environment, 35(4), 385-391. CrossRef Google Scholar

Yi, W., Li, F.-L., \& Phelps, N. A. (2008). Study on China's edge city. Urban Planning International, 4. Retrieved February 28, 2009, from http://www.upoplanning.org/en/detail.asp?articleID $=1286$ 